\title{
Effects of Tribulus terrestris Fruits on Renal and Lung Tissues in Female Mice Administered with Cadmium
}

\author{
Ahmed Sami Farhan \\ College of Science / University of Anbar, Iraq \\ *Corresponding author's Email: Ahmed.sami@uoanbar.edu.iq; (DORCiD: 0000-0003-0271-5125
}

\begin{abstract}
The current study was designed to evaluate the protective effects of Tribulus Terrestris on kidney and lung tissues against cadmium toxicity in female mice. In this regard, 20 female albino mice were randomly assigned into three groups; the first group served as the control group, the second group was given the toxic substance (cadmium 6 $\mathrm{mg} / \mathrm{kg}$ ) only, and the third group was given cadmium $(6 \mathrm{mg} / \mathrm{kg})$ plus the alcoholic extract of the Tribulus terrestris fruit $(200 \mathrm{mg} / \mathrm{kg})$. The substances were administered orally by stomach tube daily for 10 days. On the last day of the study, the animals were euthanized, and their kidney and lung were sampled for histological study. The kidney tissue in mice exposed to cadmium showed cellular inflammation, necrosis, hyperplasia, and large urinary space in Bowman's capsule in comparison to the normal appearance of tissues in the mice in the other two groups. The large aggregations of lymphocytes around the bronchus and edema in the lungs exposed to cadmium were observed. The lungs of some mice exposed to cadmium and treated with Tribulus terrestris fruit indicated normal tissue appearance, while others showed large aggregations of lymphocytes between alveolar sacs and thick interalveolar septa. The Tribulus terrestris protected the kidneys against the toxicity of the cadmium while this plant had fewer protective effects against cadmium in the lung tissue. These results demonstrated that Tribulus terrestris ameliorated cadmium toxicity.
\end{abstract}

Keywords: Cadmium, Kidney, Lung, Mice, Tribulus terrestris

\section{INTRODUCTION}

Tribulus terrestris, a flowering plant in the family Zygophyllaceae, has many medicinal and therapeutic benefits, and it is used directly to treat many diseases in different countries (Zhu et al., 2017). Many diseases treated by this plant include heart diseases, urinary tract diseases, hepatic disorders, immune diseases, and sexual dysfunctions. Also, this plant is used as dietary supplements and tonic for muscles in athletes (Hashim et al., 2014). The fruit of Tribulus terrestris contains many compounds such as alkaloids, flavonoids, glycosides, saponins, and sapogenins, having important therapeutic roles including anti-inflammatory, antibacterial, antitumor, metal chelating, antidiabetic, and analgesic activities (Miraj, 2016; Semerdjieva and Zheljazkov, 2019).

A number of herbal drugs have potent nephroprotective effects due to their diuretic, antispasmodic and antiinflammatory properties (Maharana and Dadhich, 2016). It has been shown that Tribulus terrestris is effective in lowering blood pressure and preventing kidney failure (Mohd et al., 2012). In addition, Tribulus terrestris exert hypolipidemic, cardiotonic, and hepatoprotective effects (Sivapalan, 2016). Also, Tribulus terrestris has a very important property that increases the effectiveness of antioxidant enzymes (Junior, et al., 2017; Dakshayini and Basha, 2018).

Cadmium, a heavy metal, is not a major component of the body and has no beneficial effects in the body. When entering an organ, it is very poisonous. Cadmium mainly affects kidneys and causes renal failure (Yang and Shu, 2015). Cadmium is known for its effects on proximal convoluted tubules in the kidneys, but the mechanism is uncertain. Some researchers believe that cadmium works to break down cells through programmed cell death (apoptosis) (Shagirtha and Miltonprabu, 2016). It has strong toxicity for kidneys as it breaks down DNA and increases oxidative stress (Karimi et al., 2012).

Cadmium dust inhalation affects the lung, leading to lung damage and lung cancer in smoky humans (Ganguly et al., 2018). Exposure to cadmium dust causes inflammation and changes the morphology of the lung cells, in addition, it has a negative effect on the immune system (Blum et al., 2014). The cadmium injection in the trachea of rats led to the accumulation of fluid in the alveolar spaces, then the death of type I alveolar cells, and finally lung fibrosis (Kwon et al., 2003). A study assessed the extent of DNA breakdown in animals exposed to cadmium and revealed that cadmium 
produces genotoxic effects such as DNA damage and chromosomal aberration (Skipper et al., 2016). A study showed that increasing the concentration of cadmium leads to DNA damage in the lung cells (Yang et al., 2012).

The present study aimed to evaluate the activity of Tribulus terrestris against the toxicity of cadmium. For this purpose, this study evaluated the histopathological changes of liver and kidney in mice exposed to cadmium and treated with the plant extract.

\section{MATERIALS AND METHODS}

\section{Ethical approval}

The research carried out in accordance with the ethic roles of Anbar University (Ethic committee Anbar University)

\section{Animals and study design}

Twenty two-month-old female albino mice weighing 25 to $30 \mathrm{~g}$ were obtained from the animal house of the Iraqi Center for Cancer and Medical Genetics Research, Mustansiriyah University, Iraq. They were housed in plastic cages containing sawdust. Water and diet (pellet) were available free for the mice. They were kept for six weeks for adaptation. The animals were distributed randomly to three groups: six mice in the control group, seven mice in the cadmiumexposed group (6 mg/kg), and seven mice in the cadmium-exposed and Tribulus terrestris extract (TTE)-treated group (cadmium: $6 \mathrm{mg} / \mathrm{kg}$ and TTE: $200 \mathrm{mg} / \mathrm{kg}$ ). Stomach tube was used to give cadmium and TTE to the mice daily for 10 days.

\section{Alcoholic extract preparation}

Fruits of Tribulus terrestris were collected, air dried, and then finely powdered using an electric grinder. Next, 100 $\mathrm{g}$ of powder was mixed with $1 \mathrm{~L}$ of $95 \%$ ethanol in round bottom flasks and refluxed for 6 hours. The liquid extract obtained was separated from the solid residue by vacuum filtration, concentrated using an incubator at $60{ }^{\circ} \mathrm{C}$ for $3-5$ days, and then stored at $4{ }^{\circ} \mathrm{C}$ until use (Abdel-Kader et al., 2016).

\section{Histopathological examination}

Finally, all mice were euthanized, and their kidneys and lungs were isolated. The organs were fixed in $10 \%$ formaldehyde at least 24 hours, and paraffin-formatted tissue blocks were then prepared. Tissue sections were cut into 4 $\mu \mathrm{m}$ sections by microtome and stained with hematoxylin and eosin. All stained sections were examined microscopically to observe histological changes.

\section{RESULTS}

\section{Kidney}

Histopathological examination of kidney tissues of the mice exposed to cadmium illustrated some changes. It showed the presence of cellular inflammation and necrosis (Figure 1A and B). Also, hyperplasia in convoluted tubule (Figure 1C) and large urinary space in Bowman's capsule (figure 1D) were observed.

All control animals had a normal histological appearance as shown in Figure 2. Each mouse in the cadmium and TTE-treated group had a normal appearance in both cortex and medulla of their kidney (Figure 3 ).

\section{Lung}

The results showed that cadmium affected the mice lung tissue. A large pool of lymphocytes around the bronchus and edema was observed in mice exposed to cadmium Figure 4.

Figure 5 shows the lungs of control animals whose alveolar cells and alveolar sacs appeared in normal consistency. In the cadmium and TTE-treated group, some cases had normal tissues as shown in Figure 6, while large aggregations of lymphocytes among alveolar sacs in some cases (Figure 7) and thick interalveolar septa in others were observed (Figure 8). 

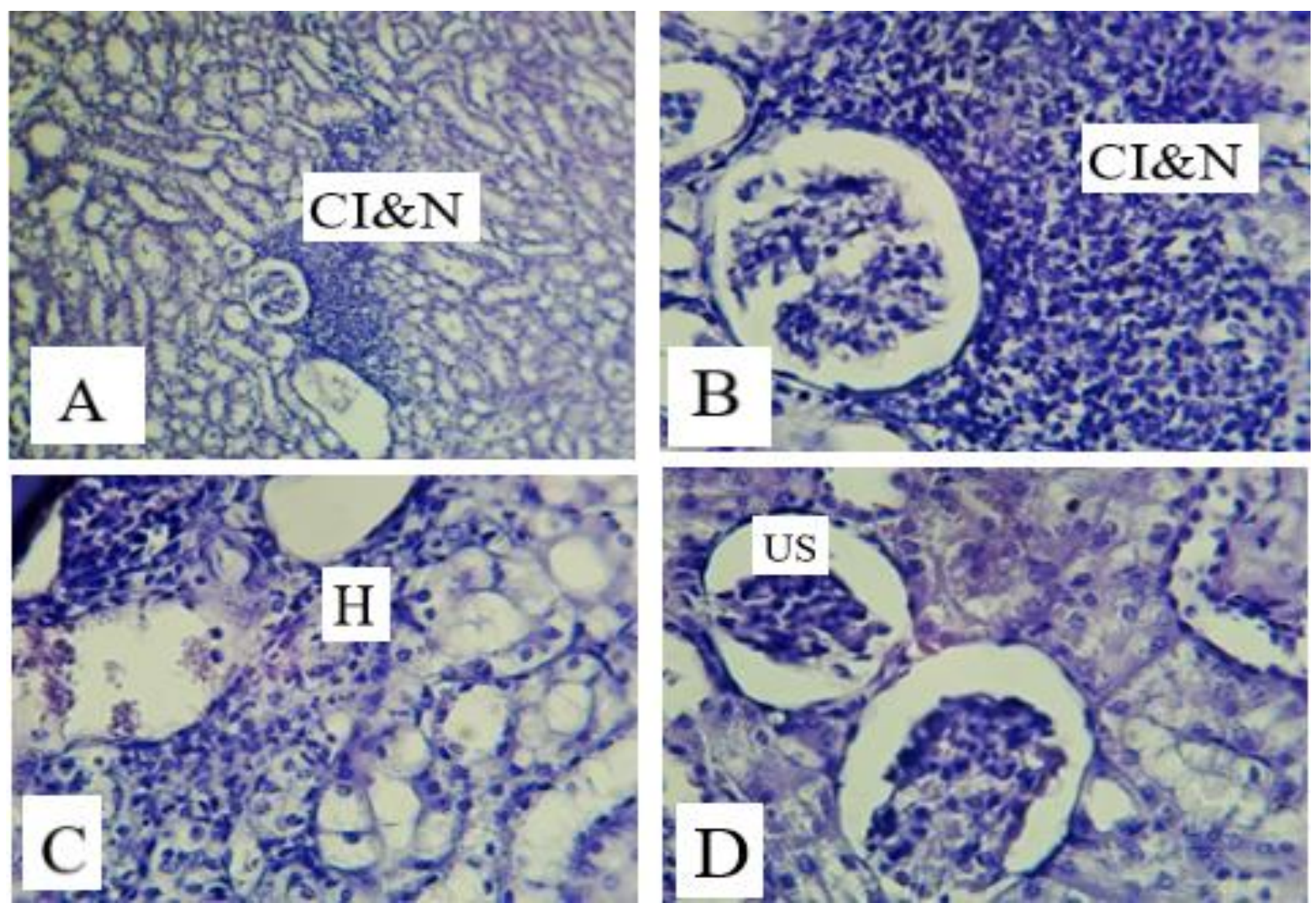

Figure 1. Cross-sections of kidneys of mice exposed to cadmium. CI \& N: Cellular inflammation and necrosis; H: hyperplasia; US: urinary space in Bowman's capsule. A and C: 10X; B and D: 40X. (H\&E).
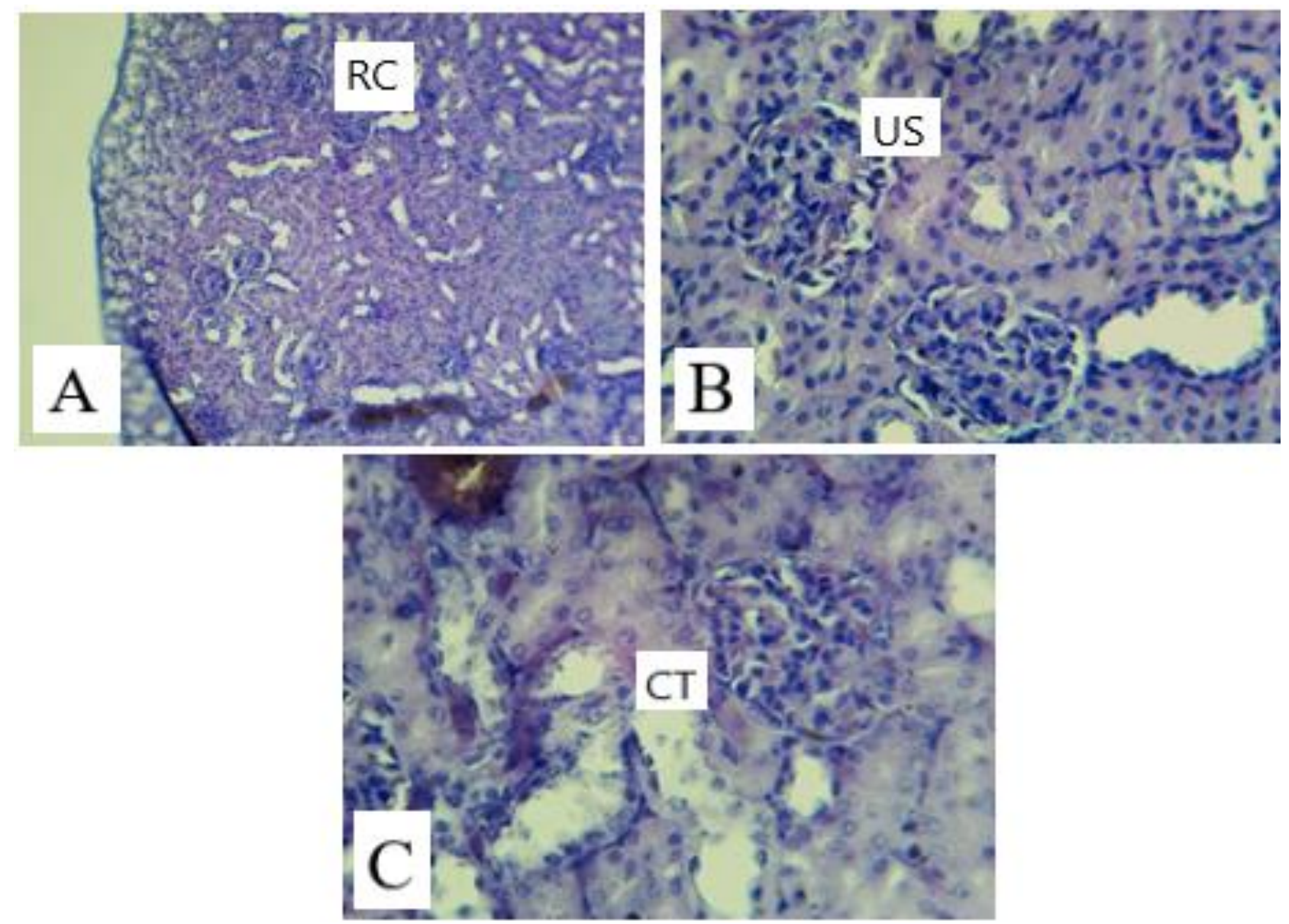

Figure 2. Cross-sections of kidneys in control mice. RC: Renal corpuscle; US: Urinary space; CT: Convoluted tubules; A: 10X, B and C: 40X, (H\&E). 

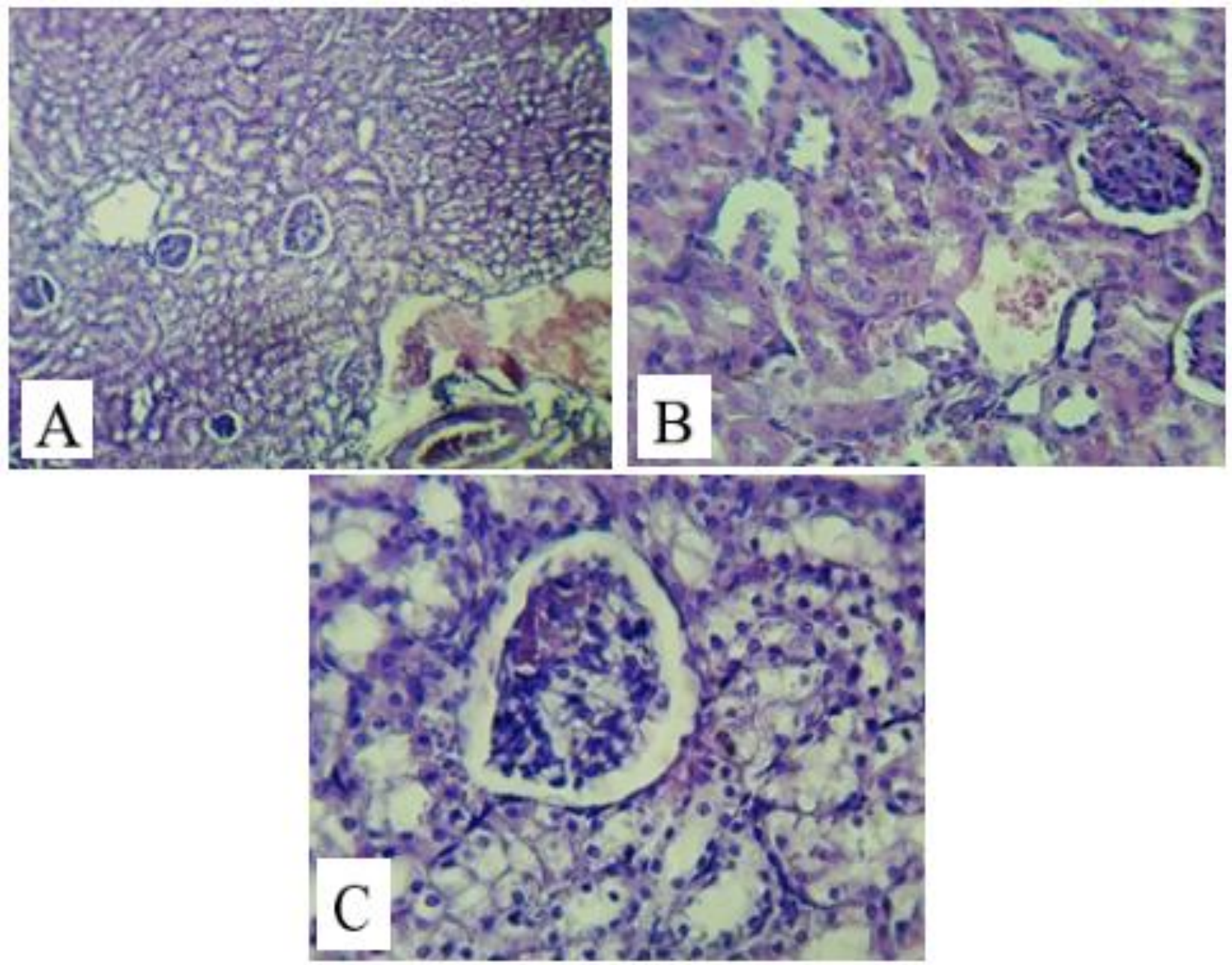

Figure 3. Cross-sections of kidneys of the mice exposed to cadmium and treated with extract of Tribulus terrestris fruit. A: 10X; B and C: 40X (H\&E).
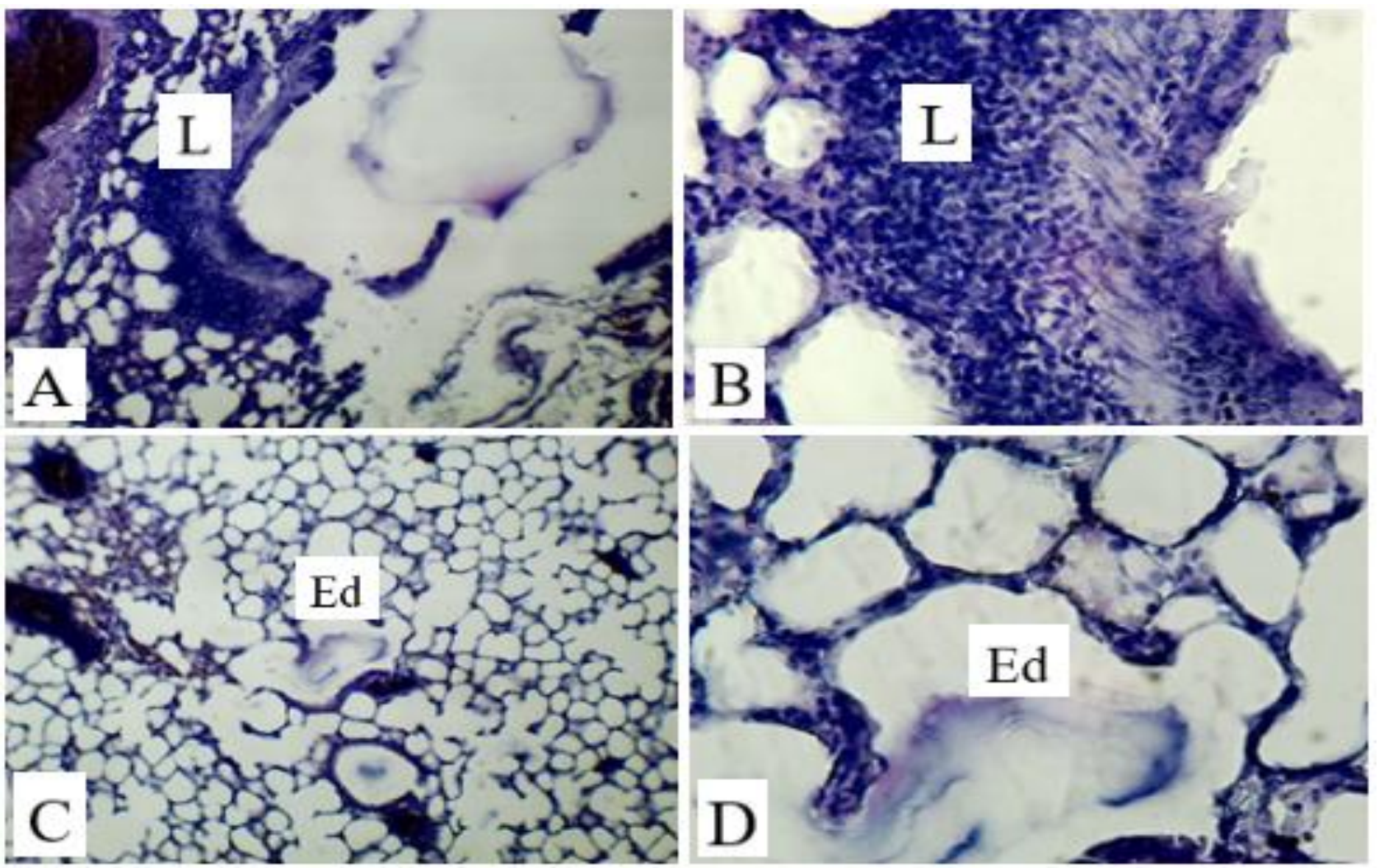

Figure 4. Lung tissues of the mice exposed to cadmium. L: Lymphocytes aggregation; Ed: edema; A and C: 10X; B and D: 40X (H\&E). 


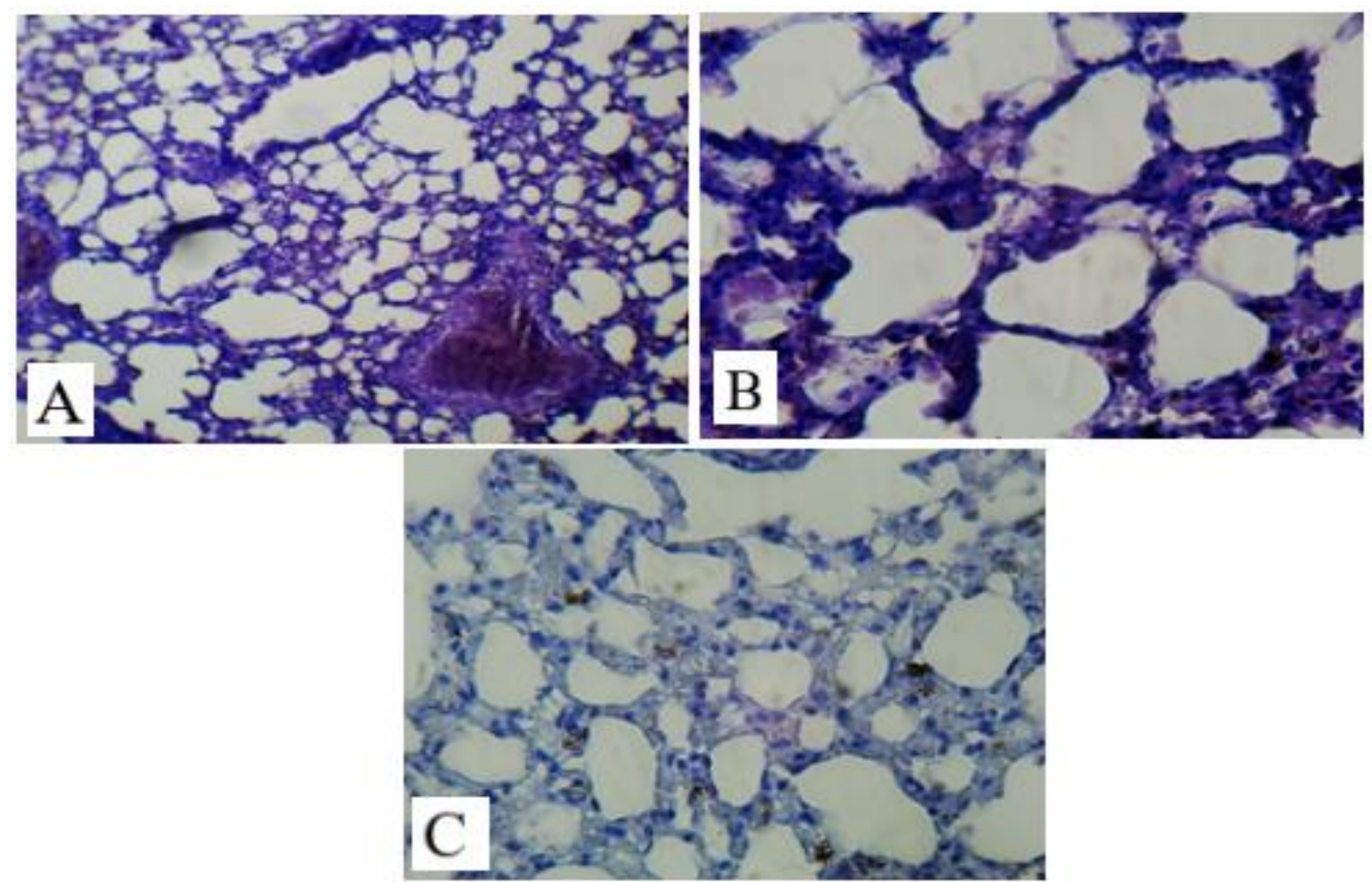

Figure 5. Histopathological examination of lung tissues of the control group. A: 10X; B and C: 40X (H\&E).
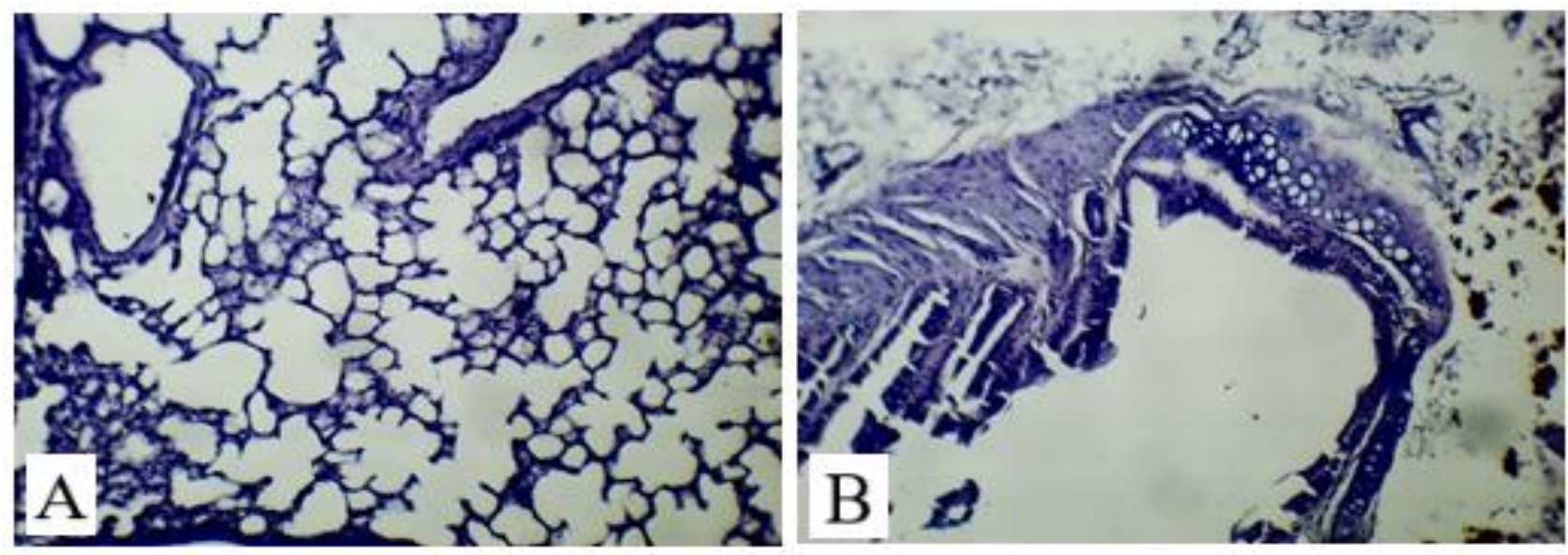

Figure 6. Lung tissues of the mice exposed to cadmium and treated with extract of Tribulus terrestris fruit. A: 10X; B: 40X (H\&E).
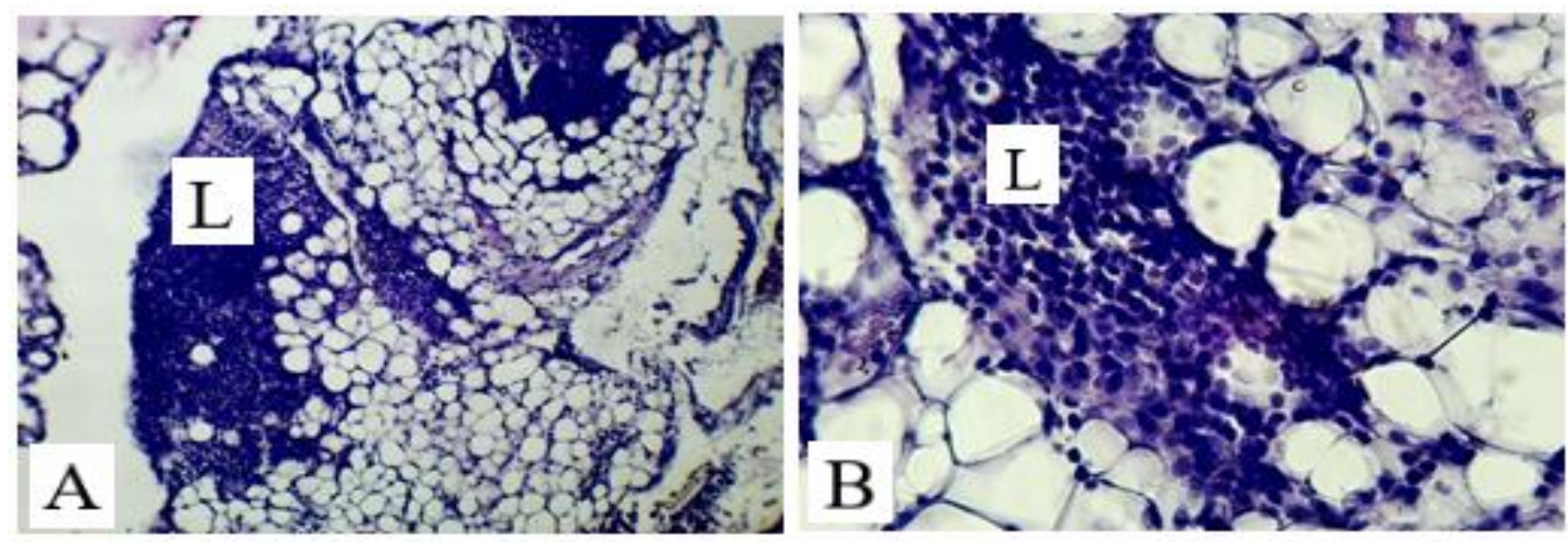

Figure 7. Histopathological examination of lung tissues of the mice exposed to cadmium and treated with extract of Tribulus terrestris fruit L: Lymphocytes aggregation; A: 10X; B: 40X (H\&E). 


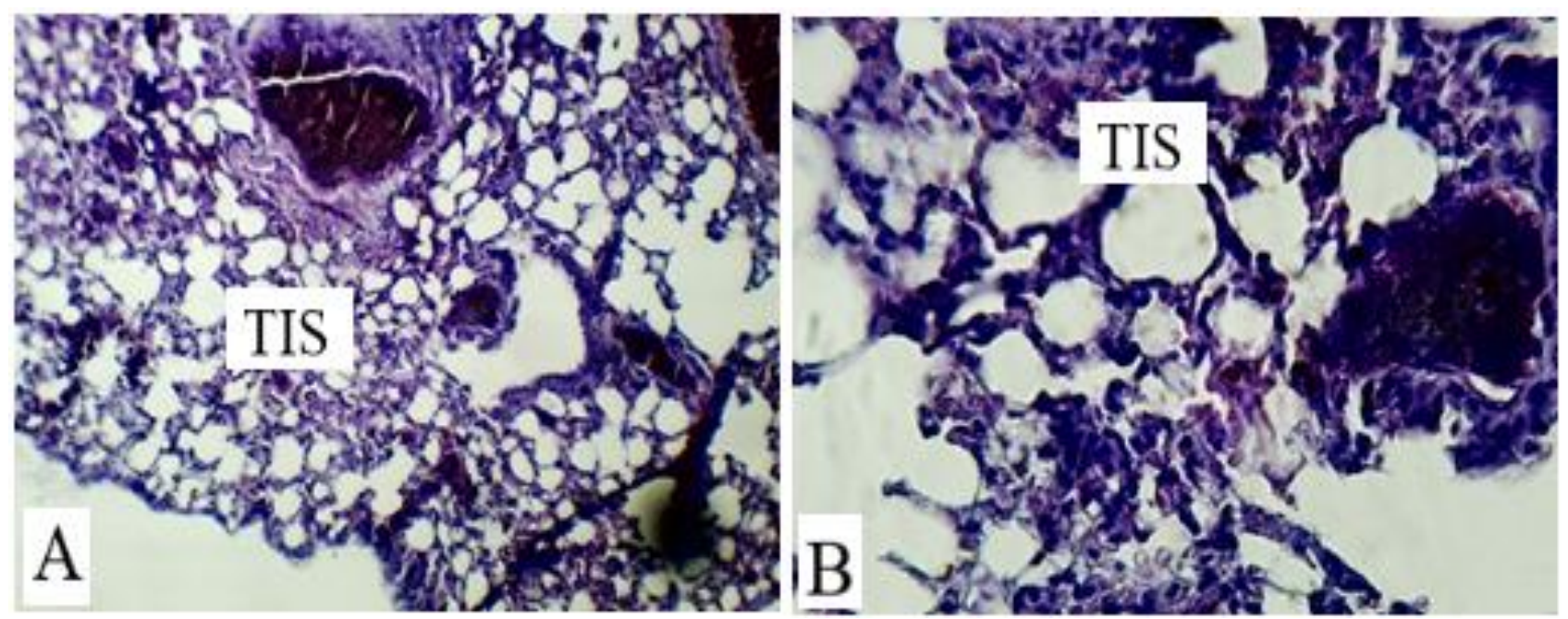

Figure 8. The lung tissues of mice exposed to cadmium and treated with extract of Tribulus terrestris fruit. TIS: thick interalveolar septa; A: 10X; B: 40X. (H \& E).

\section{DISCUSSION}

Cadmium causes many histological changes in both kidney and lung (El-Refaiy and Eissa, 2013). The results of the present study suggested that exposure to cadmium causes toxic effects and histological changes in kidney and lung tissues. The kidney and lung are known as a prominent target of cadmium because of their capability for reducing and transforming toxic materials to less toxic or non-toxic substances (Tam, 2014). Kidney and lung damage could result from cadmium accumulation in the cells. Al-Qizy (2009) showed that renal corpuscle was affected by cadmium. The reason for the breakdown of the kidney cells may be due to the release of cadmium ion from the cadmiummetallothionein complex by lysosomes of convoluted tubular cells (Tohyama et al., 1996). Another study showed that cadmium affects glomerular and tubular structures, and ultrastructure of the kidney by generating free radicals that destroy cellular components (Micali et al., 2018). Cadmium uptake by alveolar macrophage causes immune dysfunction in the lung (Cox et al., 2016). Previous data revealed that edema, cellular infiltration, and immune disturbance occurred in lung affected by cadmium administration (Jelena et al., 2019). Cadmium is a highly oxidant metal and the plants containing antioxidant compounds such as flavonoids, alkaloids, and phenolic compounds have the potential to be used against cadmium toxicity (Kumar et al., 2019).

Tribulus terrestris has numerous antioxidant compounds such as polyphenols and flavonoids (Zheleva-Dimitrova et al., 2012). It has several important therapeutic properties (Sultan and Rubab, 2017). Several studies have shown that this plant had direct effects on the urinary tract as a diuretic and a uricosuric (Akram et al., 2011). The herbal extract of Tribulus terrestris improves kidney function and reduces cellular oxidative stress (Najafi et al., 2014). The results of the current work indicated that this plant can reduce the toxic effects of the heavy metal, cadmium, on the kidney and lungs. Similarly, Abdel-Kader et al. (2016) reported that Tribulus terrestris has a positive effect on the renal tissue and function. Another study found the capability of this plant to protect kidneys against heavy metals that cause kidney damages (Manikandaselvi et al., 2012). The protective effect of Tribulus terrestris could be contributed to its ability to eliminate free radicals and induce the antioxidant enzymes expression as well as the down-regulation of proinflammatory markers in cellular injuries (Ali et al., 2018).

\section{DECLARATIONS}

\section{Competing interests}

The author declares that no competing interests exist.

\section{REFERENCES}

Abdel-Kader MS, Al-Qutaym A, Saeedan, ASB, Hamad AM and Alkharfy KM (2016). Nephroprotective and hepatoprotective effects of Tribulus terrestris L. growing in Saudi Arabia. Journal of Pharmacy and Pharmacognosy Research, 4(4): 144-152. Available at: http://jppres.com/jppres/nephroprotective-effects-of-tribulus-terrestris/

Akram M, Asif HM, Akhtar N, Shah PA, Uzair M, Shaheen G. Shamim T, Shah SMA and Ahmad K (2011). Tribulus terrestris Linn.: A review article. Journal of Medicinal Plants Research, 5(16): 3601-3605. Available at: https://academicjournals.org/journal/JMPR/articleabstract/816606740200

Ali SI, Gaafar AA, Abdallah AA, El-Daly SM, El-Bana M and Hussein J (2018). Mitigation of Alpha-Cypermethrin-Induced Hepatotoxicity in Rats by Tribulus terrestris rich in antioxidant compounds. Jordan Journal of Biological Sciences, 11(5): 517-525. Available at: 
http://jjbs.hu.edu.jo/files/vol11n5/Paper\%20Number\%207.pdf

AL-Qizy NMA (2009). Effect of Cadmium in Some physiological and histological Parameters to Laboratory Mice Mus musculus. (Thesis): Basra University College of Veterinary. Available at: https://iqdr.iq/search?view=3b4bd40b1dc8f320ce64030e5cbfa8ca

Blum JL, Rosenblum LK, Grunig G, Beasley M B, Xiong JQ and Zelikoff JT (2014). Short-term inhalation of cadmium oxide nanoparticles alters pulmonary dynamics associated with lung injury, inflammation, and repair in a mouse model. Inhalation Toxicology Journal, 26(1): 48-58. DOI: https://www.doi.org/10.3109/08958378.2013.851746

Cox JN, Rahman MA, Bao S, Liu M, Wheeler SE and Knoell DL (2016). Cadmium attenuates the macrophage response to LPS through inhibition of the NF-kB pathway. American Journal Physiology Lung Cell Molecular Physiology, 311: 754-765. https://doi.org/10.1152/ajplung.00022.2016

Dakshayini PN and Mahaboob BP (2018). Tribulus terrestris fruit extract improves antioxidant defense in female reproductive tract: A comprehensive study in diabetic rats. Journal of Innovations in Pharmaceutical and Biological Sciences, 5 (2): 101-107. Available at: http://www.jipbs.com/VolumeArticles/FullTextPDF/395_JIPBSV5I217.pdf

El-Refaiy AI and Eissa FI (2013). Histopathology and cytotoxicity as biomarkers in treated rats with cadmium and some therapeutic agents. Saudi Journal of Biological Sciences, 20: 265-280. DOI: https://www.doi.org/10.1016/j.sjbs.2013.02.004

Ganguly K, Levanen B, Palmberg L, Akesson A and Linden A (2018). Cadmium in tobacco smokers: a neglected link to lung disease. Europe Respiration Review, 27: 170122. DOI: https://www.doi.org/10.1183/16000617.0122-2017

Hashim S, Bakht T, Mareat K and Jan A (2014). Medicinal properties phytochemistry and pharmacology of Tribulus terrestris L. (Zygophyllaceae). Pakistan Journal of Botany, 46(1): 399-404. Available at: $\underline{\text { Link }}$

Jelena K, Marina N, Dina T, Aleksandra PA, Mirela U, Maja CM, Jelena M, Milena K and Ivana M (2019). Subchronic oral cadmium exposure exerts both stimulatory and suppressive effects on pulmonary inflammation/immune reactivity in rats. Biomedical Environment Science Journal, 32(7): 508-519. DOI: https://www.doi.org/10.3967/bes2019.068

Junior EPS, Gorjao R and Lambertucci RH (2017). Tribulus Terrestris' Supplementation improves the antioxidant system of resistance trained subjects. SL Nutrition and Metabolism Journal, 1(1): 113. 107. Available at: https://scientificliterature.org/Metabolism/Metabolism-17-113.pdf

Karimi MM, Sani MJ, Mahmudabadi AZ, Sani AJ and Khatibi SR (2012). Effect of acute toxicity of cadmium in mice kidney cells. Iranian Journal of Toxicology, 6 (18): 691-698. Available at: http://ijt.arakmu.ac.ir/article-1-148-en.html

Kumar A, Pandey R, Siddiqi NJ and Sharma B (2019). Oxidative stress biomarkers of cadmium toxicity in mammalian systems and their distinct ameliorative strategy. Journal of Applied Biotechnology \& Bioengineering, 6(3): 126-135. DOI: https://www.doi.org/https://doi.org/10.15406/jabb.2019.06.00184

Kwon KY, Jang JH, Kwon SY, Cho CH, Oh HK and Kim SP (2003). Cadmium induced acute lung injury and TUNEL expression of apoptosis in respiratory cells. Journal of Korean Medical Sciences, 18: 655-662. DOI: https://www.doi.org/10.3346/jkms.2003.18.5.655

Maharana L and Dadhich OP (2016). Review on role of herbal drug in the prevention and management of kidney disease. Ayushdhara Journal, 3(1): 500-508. Available at: Link

Manikandaselvi S Ramya D Ravikumar R and Thinagarbabu R (2012). Evaluation of antinephrotoxic potential of Azima tetracantha Lam. and Tribulus terrestris Linn. International Journal of Pharmacy and Pharmaceutical Sciences, 4(3): 566-568. DOI: https://www.doi.org/10.1155/2018/9162946

Miraj S (2016). Tribulus terrestris: Chemistry and pharmacological properties. Der Pharma Chemica Journal, 8(17):142-147. Available at: https://www.scopus.com/inward/record.uri?eid=2-s2 ...

Mohd J, Akhtar AJ, Abuzer A, Javed A, Ali M, and Ennus T (2012). Pharmacological Scientific evidence for the promise of Tribulus terrestris. International Research Journal of Pharmacy, 3(5): 403-406. Available at: http://irjponline.com/admin/php/uploads/1133_pdf.pdf

Najafi H Firouzifar MR Shafaat O Ashtiyani SC and Hosseini N (2014). Protective effects of Tribulus terrestris L extract against acute kidney injury induced by reperfusion injury in rats. Iranian Journal of Kidney Diseases, 8(4): 292-298. Available at: https://europepmc.org/article/med/25001135

Semerdjieva IB and Zheljazkov VD (2019). Chemical constituents, biological properties, and uses of Tribulus terrestris: A review. Natural Product Communications, 14(8): 1934578X19868394. DOI: https://www.doi.org/10.1177/1934578X19868394

Shagirtha K and Miltonprabu S (2016). Cadmium and apoptosis: A molecular approach. research \& reviews: Journal of Toxicology, 6: 1-10. Available at:

http://medicaljournals.stmjournals.in/index.php/RRJoT/login?source=\%2Findex.php\%2FRRJoT\%2Farticle\%2Fview\%2F1324\%2F1022\&login Message=payment.loginRequired.forArticle

Sivapalan SR (2016). Biological and pharmacological studies of Tribulus terrestris Linn: A review. International Journal of Multidisciplinary Research and Development, 3(1): 257-265. Available at: Link

Skipper A, Sims JN, Yedjou CG and Tchounwou PB (2016). Cadmium chloride induces DNA damage and apoptosis of human liver carcinoma cells via oxidative stress. International Journal of Environmental Research and Public Health, 13(88): 1-10. DOI: https://www.doi.org/10.3390/ijerph13010088

Sultan A and Rubab SL (2017). Tribulus terrestris-an ethnomedical \& phytochemical review. Archives of Natural and Medicinal Chemistry, 106: 1-10. DOI: https://www.doi.org/10.29011/ANMC-106.000006

Tam WS (2014). Toxicology handbook. European Journal of Emergency Medicine, 21:391-392. DOI: https://www.doi.org/10.1097/mej.0b013e32836385e9

Tohyama C, Suzui JS, Homma S, Karasawa M, Kuroki T, Nishimura H and Nishimura N (1996). Testosterone dependent induction of metallothionein in genital organs of male rats. Journal of Biochemistry, 317: 97-102. DOI: https://www.doi.org/10.1042/bj3170097

Yang H and Shu Y (2015). Cadmium transporters in the kidney and cadmium-induced nephrotoxicity. International Journal of Molecular Sciences, 16: 1484-1494. DOI: https://www.doi.org/10.3390/ijms16011484

Yang XF, Ge YM, Zhang HT, Ning HM, Jiang JQ, Qi YH and Wang ZL (2012). Damaging effects of water-borne cadmium chloride on DNA of lung cells of immature mice. Genetics and Molecular Research Journal, 11(4): 4323-4329. DOI: https://www.doi.org/10.4238/2012.September.25.2

Zheleva-Dimitrova D, Obreshkova D and Nedialkov P (2012). Antioxidant activity of Tribulus terrestris - a natural product in infertility therapy. International Journal of Pharmacy and Pharmaceutical Sciences, 4(4): 508-511. Available at: https://pdfs.nutramedix.ec/Tribulus\%20terrestris\%20-\%20Antioxidant\%20(infertility).pdf

Zhu W, Du Y, Meng H, Dong Y and Li L (2017). A review of traditional pharmacological uses, phytochemistry, and pharmacological activities of Tribulus terrestris. Chemistry Central Journal, 11:60. 1-16. DOI: https://www.doi.org/10.1186/s13065-017-0289-х 